\title{
TEMPORAL AND SPATIAL VARIABILITY OF STRUCTURE DEPENDENT PROPERTIES OF A VOLCANIC ASH SOIL UNDER PASTURE IN SOUTHERN CHILE
}

\author{
Dorota Dec $^{1 *}$, José Dörner ${ }^{1}$, and Oscar Balocchi ${ }^{1}$
}

\begin{abstract}
Prairies are a main source for livestock feeding in southern Chile. The aim of this research was to define how grazing events and natural wetting and drying cycles (WD) affect the spatial and temporal variability of the soil's structural properties. The investigation was conducted in a Duric Hapludand, Valdivia Series. Penetration resistance (PR) and volumetric water content (WC), measured in situ, were used to prepare maps which show i) temporal (1383 to 3047 $\mathrm{kPa}$ for 46 to $16 \% \mathrm{WC}$ ) and spatial changes, and ii) grazing events as an important factor influencing spatial changes in PR (differences of $3421 \mathrm{kPa}$ between max and min values). Grazing and WD cycles induced changes in the soil's mechanical stability and pore functions, which indicate that structure-dependent properties are dynamic. During the study, variations between 0.3 and $0.9 \log \mu \mathrm{m}^{2}$ were detected for air permeability $\left(\mathrm{k}_{\mathrm{a}}\right)$, whereas air capacity (ACp) ranged between 5 and $18 \%$. Soil mechanical strength also varied over time and showed changes in PR. The same instrument, however, cannot be used to identify changes in soil pore functions. Generally, after grazing events, soil deformation induced a reduction of air capacity and permeability; however, after WD cycles, soil pores were able to recover their functional integrity.
\end{abstract}

Key words: penetration resistance, water content, mechanical strength, porous system, Andisol.

$\mathrm{D}$ ifferent types of soil management are the object of exhaustive investigations since it is well known that, for example, tillage or grazing management not only influences crop productivity (Lapen et al., 2001; Borghei et al., 2008), but also soil properties (Raper et al., 2000; Armas-Espinel et al., 2003; Krümmelbein et al., 2009; Gebhardt et al., 2009, Dörner et al., 2009a; 2009b). Soil properties are very important in volcanic ash soils because, as Dorel et al. (2000) and Dörner et al. (2010) have already confirmed, they are prone to deformation not only due to mechanical stress (e.g., soil trampling), but also as a consequence of hydraulic stress (e.g., wetting and drying cycles). This is relevant in southern Chile because there has been an important land use change from native forests (pristine systems) to crops and pastures (Aguayo et al., 2009). Pastures are the main resource to feed livestock throughout the year (Balocchi, 2002) and causes high soil mechanical stress. Therefore, to achieve sustainable management, it is essential to investigate the

${ }^{1}$ Universidad Austral de Chile, Facultad de Ciencias Agrarias, Casilla 567, Valdivia, Chile. "Corresponding author (dorkadd@gmail.com). Received: 21 September 2010.

Accepted: 8 February 2011. effect of, for example, compaction by animal trampling on soil functions, such as water or air holding capacity and conductivity.

It is widely known that a well-developed and stable soil structure and continuous pore system is important for water, air, and heat transport (Horn et al., 1994; Dec, 2006; Bormann and Klaassen, 2008; Dec et al., 2009). These structure-dependent properties, however, not only temporal change, but also spatial change as a result of natural phenomena such as wetting and drying cycles (WD) (Peng et al., 2007; Dörner et al., 2009a), thawing and freezing (Unger, 1991; Bormann and Klaassen, 2008), human activities as in different tillage management practices (Strudley et al., 2008, Horn and Fleige, 2009), grazing events (Peth and Horn, 2006; Krummelbein et al., 2009), biological activity (Fazekas, 2005), plant cover and topography (Zhao et al., 2007), which can be locally modified by erosion and deposition processes. As a result of WD cycles, soil constantly shrinks and swells, improves its structure by increasing tensile strength of the bonds between soil particles leading to the formation of water-stable aggregates and new pores as a consequence of crack formation (Horn and Baumgartl, 2002). The latter allows the soil to recover after damages (Batey, 2009). 
Rainfall is a very important factor influencing the soil's structure-dependent properties and cannot be ignored in southern Chile since yearly precipitation and evaporation normally reach 2500 and $807 \mathrm{~mm}$, respectively (Novoa et al., 1989). Therefore, temporal changes in soil properties must be expected in volcanic ash soils because of their high shrinkage (Dorel et al., 2000; Dörner et al., 2009a), but low swelling capacity (Armas-Espinel et al., 2003; Dörner et al., 2009a).

Soil tillage and grazing intensity are factors which influence the soil's physical properties. Drewry (2008) mentioned that grazing animals, such as cattle, can exert great forces on the soil and cover a larger paddock area than wheeled vehicles used in cropping systems. Intensively managed grazing systems can result in reduced pasture yield, biodiversity, soil quality, and soil weight-bearing capacity, as well as increasing soil compaction, erosion, and overland flow (Bilotta et al., 2007; Zhao et al., 2007; Reszkowska et al., 2009). Greenwood et al. (1997) also found significant differences in hydraulic soil properties, such as unsaturated hydraulic conductivity, soil strength, and bulk density, in the soil surface of ungrazed and grazed pastures. Negative changes in soil structure caused by animals have already been described by Proffitt et al. (1995), Pietola et al. (2005), Peth and Horn (2006), and Krümmelbein et al. (2009). Soil deformation, however, not only depends on applied stress, but also on actual water content since it controls aggregate stability at the time of trampling (Horn and Fleige, 2003) and governs soil bearing capacity (precompression stress) (Horn and Fleige, 2009). Under wet conditions, soil bearing capacity is usually lower than the pressure exerted by animals (180 kPa). In such conditions, animal grazing and trampling lead to poaching (Drewry, 2006), thus creating a critical situation causing topsoil swelling and loss of soil stability and resistance, which affect other physical and mechanical properties. On the other hand, under dry conditions, bearing capacity increases to values higher than the pressure exerted by animals, and soil structural integrity is maintained.

Soil compaction by animal hooves induces pore loss affecting soil ability to transport air and soil solutions (macropores: > $50 \mu \mathrm{m}$ ). This, in turn, influences soil hydrology and directly deteriorates the living conditions of micro fauna and plant growth since the affected soil is also the root growth zone. Grazing and the resulting compaction or poaching can provoke soil erosion. Plants are mashed, eaten, and displaced, thus exposing bare soil to the influence of water and/or wind. These processes are clearly undesirable since it takes a long time, exceeding $18 \mathrm{mo}$, for soil to fully recover to previous conditions (Drewry, 2008). The temporal and spatial character of these changes is the result of grazing animals kneading the soil surface irregularly and subjecting it to different stress.

The property used to evaluate temporal and spatial changes in soil structure, in addition to soil compaction, is penetration resistance, which describes soil strength (Draghi et al., 2005) or resistance to root growth. This property can be directly measured in the field with a penetrometer. This tool is widely used because of its simplicity, low cost of analysis, and the great amount of information that can be gathered in a short period of time. However, defining the theoretical basis needed to extrapolate results for different soil environments (Lloyd and Collis-George, 1982) can be a problem since penetration resistance depends heavily on soil water content (Horn and Fleige, 2009).

Based on the simplicity of measuring soil penetration resistance and volumetric water content in the field, this study aimed to: $i$ ) define the spatial and temporal variability of soil strength using a penetrometer and Time Domain Reflectometry (TDR), ii) determine temporaldependent soil structure parameters affected by grazing and natural WD cycles, and finally iii) o assess if the penetrometer is an effective tool to estimate changes in soil pore functions.

\section{MATERIAL AND METHODS}

\section{Soil and management}

The experimental field is located in Valdivia (39 $48^{\prime} \mathrm{S}$, $73^{\circ} 15^{\prime}$ W, 12 m a.s.1.), Chile. The soil is a Duric Hapludand (Valdivia Series, CIREN, 2003). The soil is moderately deep with a silty loam texture in the first centimeters, which then becomes coarser in deeper horizons. The topography is complex with slopes between 5 and $8 \%$ (CIREN, 2003). The climate is moderately rainy with an average temperature of $12{ }^{\circ} \mathrm{C}$. Precipitations average $2500 \mathrm{~mm}$ annually, which are more intense in winter. Before starting the experiment, the soil of the naturalized prairie (> 15 yr old) was cultivated and Lolium perenne L. and Trifolium repens L. were seeded in April 2008. The total area of the experiment was $2400 \mathrm{~m}^{2}$ (six 20 x $20 \mathrm{~m}$ plots). Grazing (two Holstein Friesian cows; 500 kg 400 $\mathrm{m}^{-2}$ ) related to grass disposal (1700 to $2400 \mathrm{~kg} \mathrm{DM}$ in the beginning and 1200 to $1500 \mathrm{~kg} \mathrm{DM}$ at the end of winter and summer, respectively) began in September 2008 and was the same in all plots. Therefore, we evaluated the temporal and spatial changes in soil structural properties of soil subjected to the same grazing management.

\section{Field measurements and soil sampling}

Field measurements and soil samplings (Figure 1), defined according to grazing events and wetting and drying cycles, were conducted from November 2008 to 


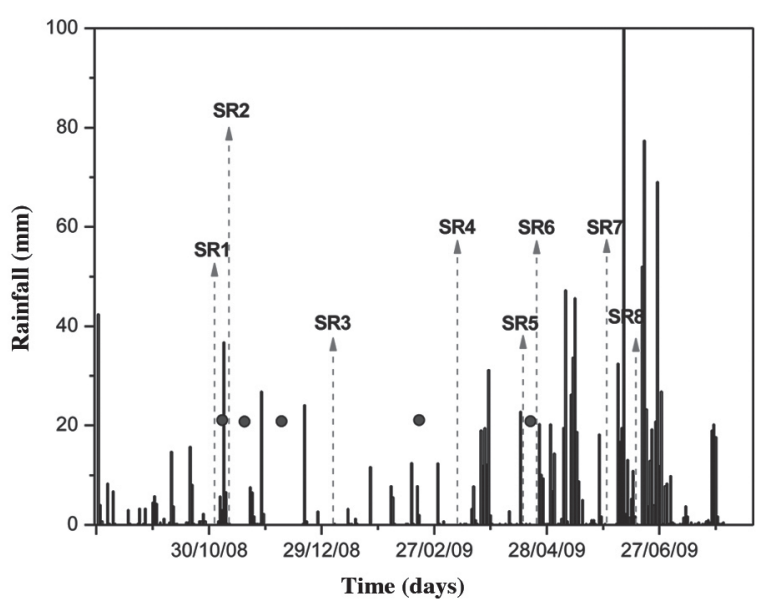

Figure 1. Development of rainfall during the experiment. Arrows show sampling events (SR1 to SR8) and circles indicate grazing events.

June 2009 as follows: SR1: 11.03.08, SR2: 11.10.08, SR3: 01.09.09, SR4: 03.10.09, SR5: 04.15.09, SR6: 04.20.09, SR7: 05.28.09, and SR8: 06.22.09.

Water content (WC) and penetration resistance (PR) were measured in each plot, which was arranged along transects $3 \mathrm{~m}$ apart and divided into 13 points (separation: $1.5 \mathrm{~m}$ ) for a total of 546 points. Volumetric water content was measured by Time Domain Reflectometry (TDR 200 Soil Multimeter FOM/mts, Easy Test, Lublin, Poland), which was previously calibrated with disturbed material $(<2 \mathrm{~mm})$ to prepare soil cores with defined bulk densities similar to those observed in the field, and approximate volumetric water content of $10,20,30,40$, and $50 \%$. Penetration resistance was determined with a coin penetrometer (06.01 Hand Penetrometer, Eijekelkamp Agrisearch Equipment, Giesbeek, The Netherlands) at a depth of $10 \mathrm{~cm}$, which corresponds to the depth most affected by animal trampling as pointed out by Chappell et al. (1971), Greenwood et al. (1997), Drewry and Paton (2000), Drewry et al. (2004), and Drewry (2006). Both PR and WC values were mapped with the Surfer software (Systat Software Incorp., Utah, USA). When field measurements were taken, undisturbed soil samples (in metallic cylinders) and soil aggregates (in boxes) were collected from 2 to $10 \mathrm{~cm}$ depths.

\section{Mechanical properties}

Aggregate strength (AS) was determined by a crushing test (Dexter, 1988). First, 20 aggregates collected from the field were carefully selected, saturated, and equilibrated at water tensions of 60 and $30000 \mathrm{hPa}$. Each of them was then crushed between two parallel splints as a result of an increase in the amount of water at one end of one of the splints. The weight of the water needed to crush an aggregate was registered. Finally, aggregates were oven- dried at $105{ }^{\circ} \mathrm{C}$ for $24 \mathrm{~h}$ to determine gravimetric water content.

To determine precompression stress $(\mathrm{Pv})$, undisturbed soil samples collected in metallic cylinders $\left(120 \mathrm{~cm}^{3}\right)$ were saturated by capillary rise from beneath and then equilibrated at $60 \mathrm{hPa}$ water tension. Samples were then weighed and air conductivity $\left(\mathrm{k}_{1}\right)$ measured with an air flow meter (described below). The consolidation curve was determined in an odometer (T controls, Italy), samples were weighed, and air conductivity was measured again. To determine soil bulk density, samples were oven-dried at $105{ }^{\circ} \mathrm{C}$ for $24 \mathrm{~h}$. Precompression stress or bearing capacity was calculated according to Casagrande (1936).

\section{Pore functions}

Undisturbed soil samples in metallic cylinders $\left(220 \mathrm{~cm}^{3}\right)$ were taken from the field to determine air capacity and permeability. They were then saturated by capillary rise from beneath and finally drained at $60 \mathrm{hPa}$. Air capacity (ACp) was calculated as the difference between total porosity and volumetric water content at $60 \mathrm{hPa}$ water suction. Air permeability $\left(\mathrm{k}_{\mathrm{a}}\right)$ was calculated from air conductivity (Dörner and Dec, 2007). The latter was measured by the steady state method where a pressure difference of $1 \mathrm{hPa}$ is applied to the soil sample to allow a laminar air flow through it. Equipment included 5 flow meters with different scales to measure air conductivities from 0.1 to $50 \mathrm{~L} \mathrm{~min}^{-1}$. Each measurement was replicated three times. Temperature and air pressure changes during measurement were registered according to Dörner and Horn (2006) and Dörner et al. (2009b).

\section{Statistical analyses}

Since grazing management was the same in all plots, we only evaluated the temporal and spatial changes in soil structural properties, and mean values and standard errors for all soil properties were calculated. Furthermore, the coefficient of variation for penetration resistance was determined. Air permeability values were log-transformed because of the skewed distribution (Hartge and Horn, 2009). Linear regressions were also conducted.

\section{RESULTS AND DISCUSSION}

\section{Temporal and spatial variations of penetration resistance and water content}

Measurements of penetration resistance and water content conducted under field conditions were used to prepare maps of their spatial and temporal variations (Figure 2). This form of presenting data provides valuable information not only for understanding, for example, spatial changes of investigated properties and landscape water fluxes on hilly slopes, but also 


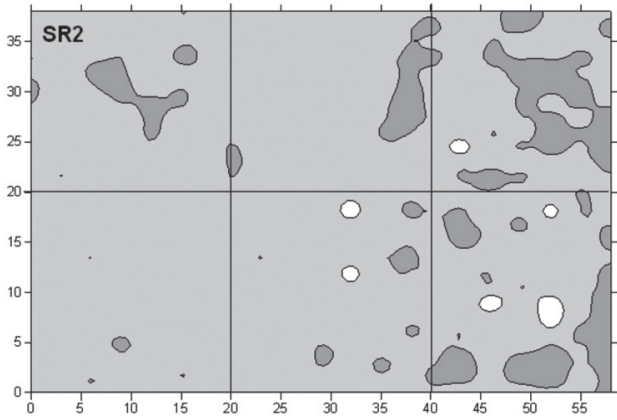

WC $(\%)$

$\mathrm{PR}(\mathrm{kPa})$
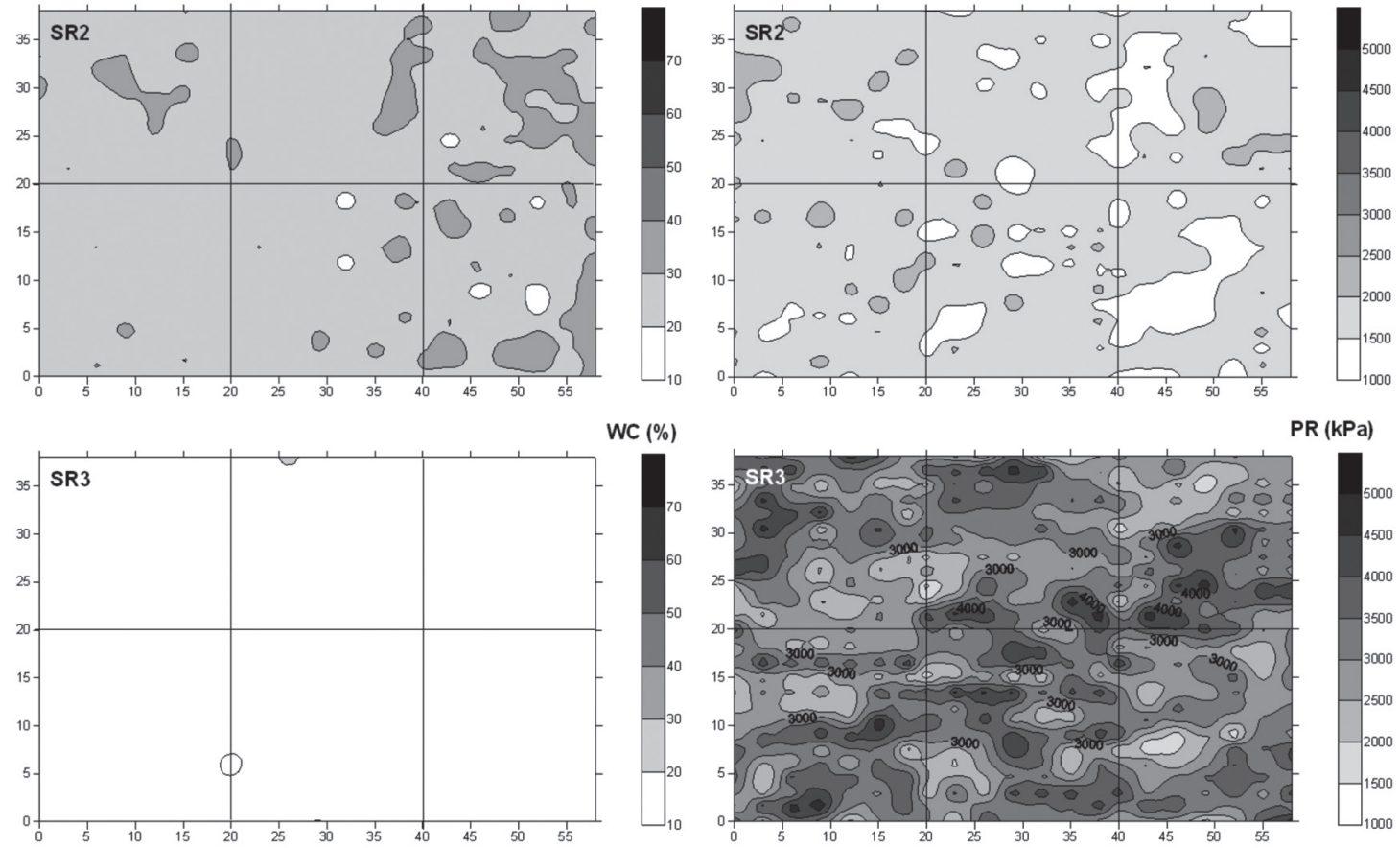

WC $(\%)$
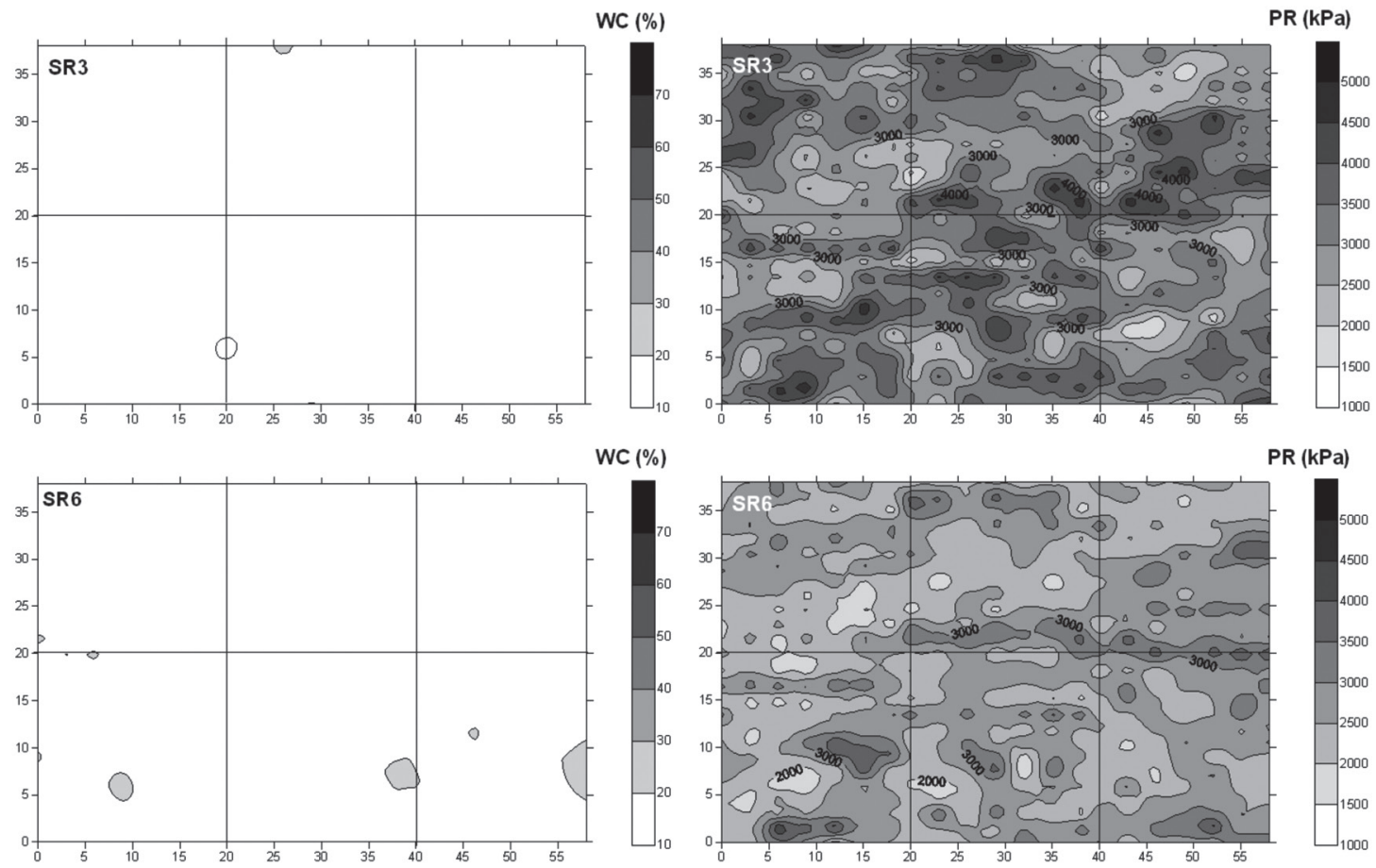

WC $(\%)$

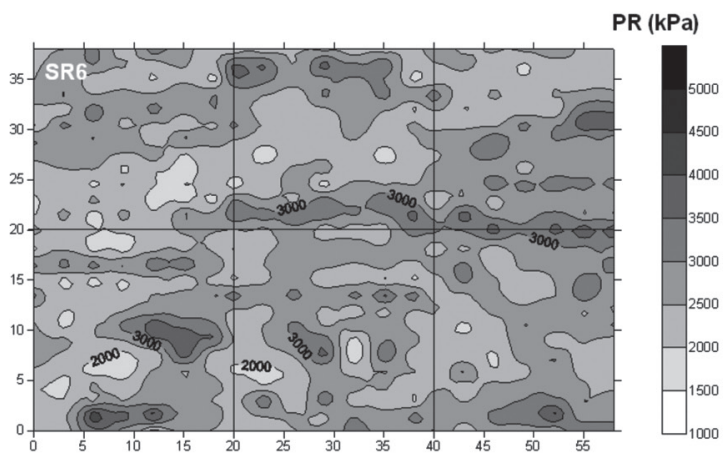

Figure 2. Spatial distribution of volumetric water content (WC) and penetration resistance (PR) in SR2 (10.11.08), SR3 (09.01.09), and SR6 (20.04.09). Mean values of WC (vol \%) and PR (kPa) for SR2: WC = 28, PR = 1691; SR3: WC = $14, P R=3143$; and SR6: $W C=15, P R=2563$.

as the basis for spatial discretization and parameter estimation in the modeled domain (Zhao et al., 2007). These maps show that both properties change spatially and temporally. According to Vanags et al. (2004) and Lapen et al. (2004), penetration resistance decreased as a function of an increase in WC (Figure 3), which is particularly true on a time scale, but not a spatial scale, as abovementioned. In wet soils, where pore space is filled with water, menisci forces cause soil particles to lose contact between each other. This, in turn, increases the soil's susceptibility to compaction and decreases PR values (Unger, 1996; Beutler et al., 2005) because of lower cohesion between particles and aggregates. During drying, water menisci forces are built up and increase PR. This phenomenon was observed especially between SR2 and the remaining samplings SR3, SR6 (Figure 2) where a $50 \%$ decrease in WC caused PR to increase $1452 \mathrm{kPa}(100 \%)$ and $872 \mathrm{kPa}(50 \%)$ between SR2-SR3 and SR2-SR6, respectively. PR values under dry conditions were higher than those presented by Sandoval-Estrada et al. (2008) for a Typic Haploxerand (values ranged between 1200 and $1500 \mathrm{kPa}$ with bulk densities lower than $\left.0.7 \mathrm{~g} \mathrm{~cm}^{-3}\right)$. However, similar and even higher values were observed by Ellies et al. (1993) and Bachmann et al. (2006) in a Typic Hapludands under different land uses (up to $2500 \mathrm{kPa}$ ) and pasture (up to $5000 \mathrm{kPa}$ and bulk densities lower than $0.8 \mathrm{~g} \mathrm{~cm}^{-3}$ ), respectively.

PR spatial changes in SR3 and SR6 were clearly observed and not related to changes in WC $(\mathrm{P}>0.05$, 


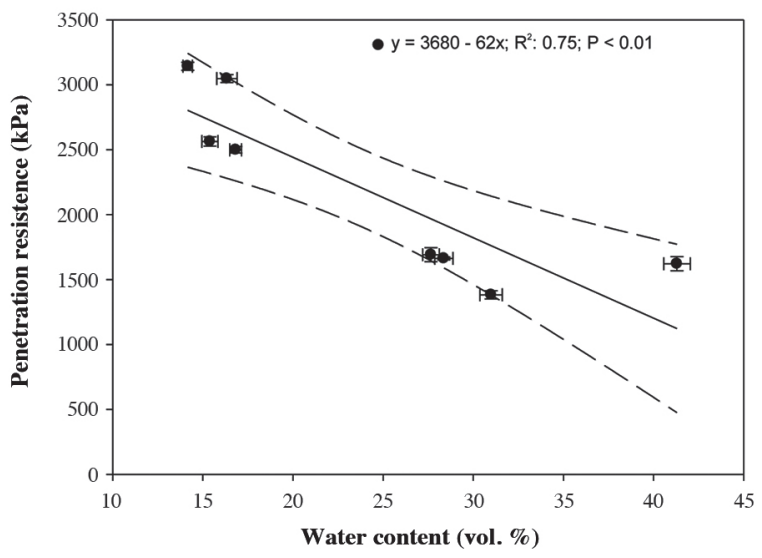

Figure 3. Penetration resistance as a function of water content. Bars indicate \pm 1 standard error $(n=546)$.

figure not shown), but certainly to soil compaction by trampling. This indicates that interpreting the relationship between PR and WC values is not always easy and errorfree since changes in WC and soil structure are very dynamic even in very short time and space intervals. In our study, an additional and important criterion for taking soil samples was the grazing events since they cause soil to be additionally sheared, compacted (Peth and Horn, 2006), deformed (Warren et al., 1986; Krümmelbein et al., 2009), kneaded, and homogenized by animal hooves. This process is not static and has to be considered as a short-term dynamic process. The effect of soil trampling on actual in situ soil strength was especially evident in the spatial changes of this property (CV of SR3 and SR6 were 26 and $21 \%$, respectively; Table 1). For example, the investigated plots in SR4 showed areas with high and low PR values with differences of up to $3421 \mathrm{kPa}(\mathrm{CV}: 27 \%)$, whereas no significant differences in WC were measured. This effect is caused by animals that move during grazing and more intensively trample areas with available pasture. Greenwood and McKenzie (2001) mentioned that the pressure that the soil surface suffers is higher during animal movement since the animal's weight is distributed on 2 or 3 hooves. This intensive treading is concentrated in areas such as entrances around troughs and camping areas
(Sears, 1956). In heavily grazed pastures, this increased local compaction can produce plastic deformation, which is undesirable given its negative consequences.

\section{Temporal variations in penetration resistance and mechanical strength}

The ever-increasing human population demands more intensive food production that requires high quality soils. On the other hand, the increasing weight of modern machinery (Van den Akker et al., 2003; Godwin et al., 2008) causes greater pressure on the soil that results in soil compaction and decreases yields. Horn and Fleige (2009) proposed that determining soil mechanical strength becomes important since knowledge about this property would allow us to avoid subsoil compaction and the corresponding negative impacts on soil functions, including yield functions for cultivated plants, habitat functions for natural plant buffering, and filtration or regulatory functions.

Soil mechanical strength at different scales (soil aggregate, cylinder, and profile) changes over time as a consequence of grazing events and WD cycles (Figure 4). Ellies et al. (1993; 2000) asserted that penetration resistance values and vane shear increase with the intensity of land use in a Typic Hapludand are different in summer and winter. Our research showed that an increase in field $\mathrm{PR}$ indicated greater aggregate strength at $\mathrm{pF} 4.6$ (AS) and precompression stress $(\mathrm{Pv})$ among SR1, SR2, and SR3. Compacted soils with combined displacement due to shearing, shrinkage, and swelling can result in denser soil with a greater number of contact points or greater forces at each single contact point and, consequently, greater internal aggregate strength. When comparing measurements of the same water content, it is also clear that grazing and stocking consistently increase soil near-surface strength (Willatt and Pullar, 1983; Mead and Chan, 1992). This shows us that decreasing WC and grazing occurrence influences soil mechanical strength on aggregate, soil volume (cylinder), and profile (first $10 \mathrm{~cm}$ soil) scales.

No grazing events were conducted and repeated wetting and drying cycles were assessed during the three last samplings. As a consequence of rainfall and increased WC, a gradual PR decrease was observed. The highest

Table 1. Volumetric water content (WC), degree of saturation (WS; mean values \pm 1 standard error), and penetration resistance (PR) (with coefficient of variation CV) during soil samplings.

\begin{tabular}{lcccccccc}
\hline & SR1 & SR2 & SR3 & SR4 & SR5 & SR6 & SR7 & SR8 \\
\hline WC, $\%$ & $41 \pm 0.7$ & $28 \pm 0.4$ & $14 \pm 0.3$ & $16 \pm 0.6$ & $17 \pm 0.3$ & $15 \pm 0.4$ & $43 \pm 0.4$ & $46 \pm 0.7$ \\
WS, \% & $83 \pm 0.7$ & $40 \pm 0.2$ & $29 \pm 0.2$ & $34 \pm 0.5$ & $24 \pm 0.2$ & $22 \pm 0.2$ & $62 \pm 0.2$ & $67 \pm 0.4$ \\
PR, kPa & 1622 & 1691 & 3143 & 3047 & 2499 & 2563 & 1663 & 1383 \\
CV $\%$ r $\%$ & 21 & 16 & 26 & 27 & 23 & 21 & 17 & 19 \\
\hline
\end{tabular}

SR: sampling times. Values correspond to the means of 546 replicates. 


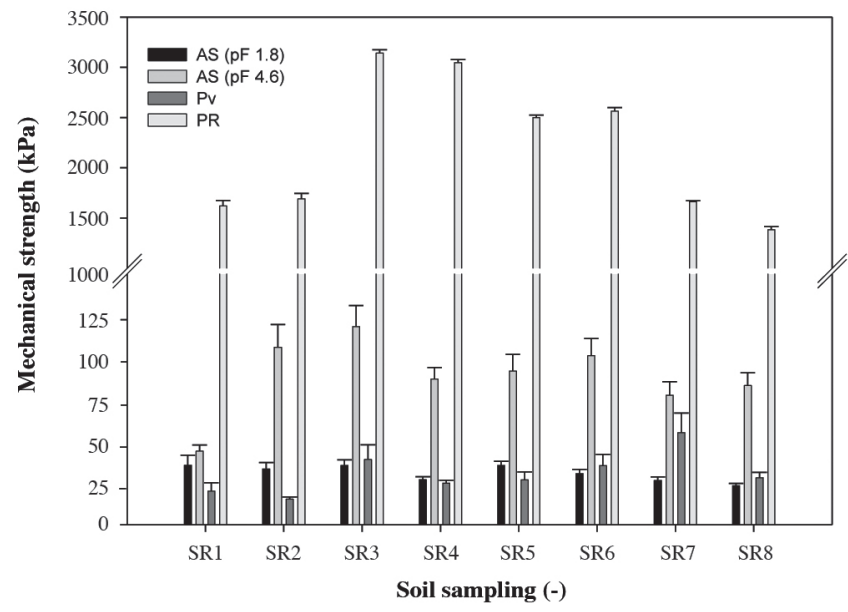

Figure 4. Mechanical strength measured at different scales (AS: aggregate strength, Pv: precompression stress, PR: penetration resistance) as a function of time (soil samplings SR1 to SR8). Bars indicate \pm 1 standard error (AS, $n=$ 20; $P v, n=6 ;$ and $P R, n=546$ ).

PR decrease was observed between SR6 and SR7, which responded to changes in WC that also caused aggregate strength to decrease. Horn et al. (1994) and Horn and Smucker (2005) have established that biological activity and kinds of organic exudates, as well as the number, intensity, and time of WD cycles greatly influence aggregate formation and strength. When soil drying and the number of shrinkage events are more intense, aggregate strength and soil mechanical stability are greater. However, these relationships and dependencies should be further investigated given the specific properties of volcanic ash soils (Dorel et al., 2000; Dörner et al., 2009a; 2009b; 2010).

Finally, it is useful to assess temporal variations in mechanical strength at different scales, and if these properties reach critical values for plant growth. According to Horn and Fleige (2009), penetration resistance and precompression stress form part of the "low indication" parameters with low significance or sensitivity to define the effect of subsoil compaction concerning crop production. Next, they stated that if values of two low indication parameters exceeded a defined limit, soil would be classified as endangered and selective measurements should be initiated (e.g., air capacity, conductivity). The highest values attained in our research were 3143 and 55 $\mathrm{kPa}$ for $\mathrm{PR}$ and $\mathrm{pV}$, respectively. While the critical PR value was greatly exceeded, $\mathrm{Pv}(60 \mathrm{hPa}$ water tension) was still at a safe level (limit value for loam soil is $90 \mathrm{kPa}$ ). High PR values can be a limiting factor for plant growth and porous system functionality since PR values are higher than $2000 \mathrm{kPa}$, defined as critical values for root growth in different soils, as in an Aridic Paleustolls, loam-textured soil described by Bengamin et al. (2003) and Borghei et al. (2008). Horn and Fleige (2009) also considered this value as limiting because it caused a "harmful change of the soil" (according to the German Federal Soil Protection Law, 1998). However, whether reduction or suppression of tillage can increase this property must be investigated, since crop response to soil compaction not only depends on compaction degree, but also on interaction among crops, soil types, and WC (Lipiec and Simota, 1994). For the soils under study that exhibit specific properties (Dorel et al., 2000; Dörner et al., 2009a; 2010), we believe that high PR should not affect root growth as it does in other soils because of low bulk density $\left(<0.9 \mathrm{~g} \mathrm{~cm}^{-3}\right)$, the great number of pores caused by the large amount of organic soil $\mathrm{C}$, and the presence of allophane, all of which are typical characteristics of Andisols (Dörner et al., 2009a; 2009b). However, this needs further study since the critical PR value varies according to soil type (Beutler et al., 2005) and cannot be directly applied to subsoil compaction given that measurements should be conducted at field capacity and can only give an overview of the differences in depthdependent values (Horn and Fleige, 2009).

\section{Temporal changes in pore functions}

Time-dependent changes observed in soil strength were also assessed for bulk density $(\mathrm{dB})$, reaffirming that the soil exhibits a dynamic behavior as a consequence of external (soil compaction) and internal (soil shrinkage) forces affecting soil porosity and its functions (Figure 5). However, no significant relationship between PR and bulk density ( $\mathrm{r}:-0.17 ; \mathrm{p}>0.1$ ) was observed during the study period (Figures 4 and 5) since PR is strongly dependent on soil WC.

One of the factors influencing the impact of soil management on $\mathrm{dB}$ is soil depth. Chappell et al. (1971) and Greenwood et al. (1997) investigated untilled and 

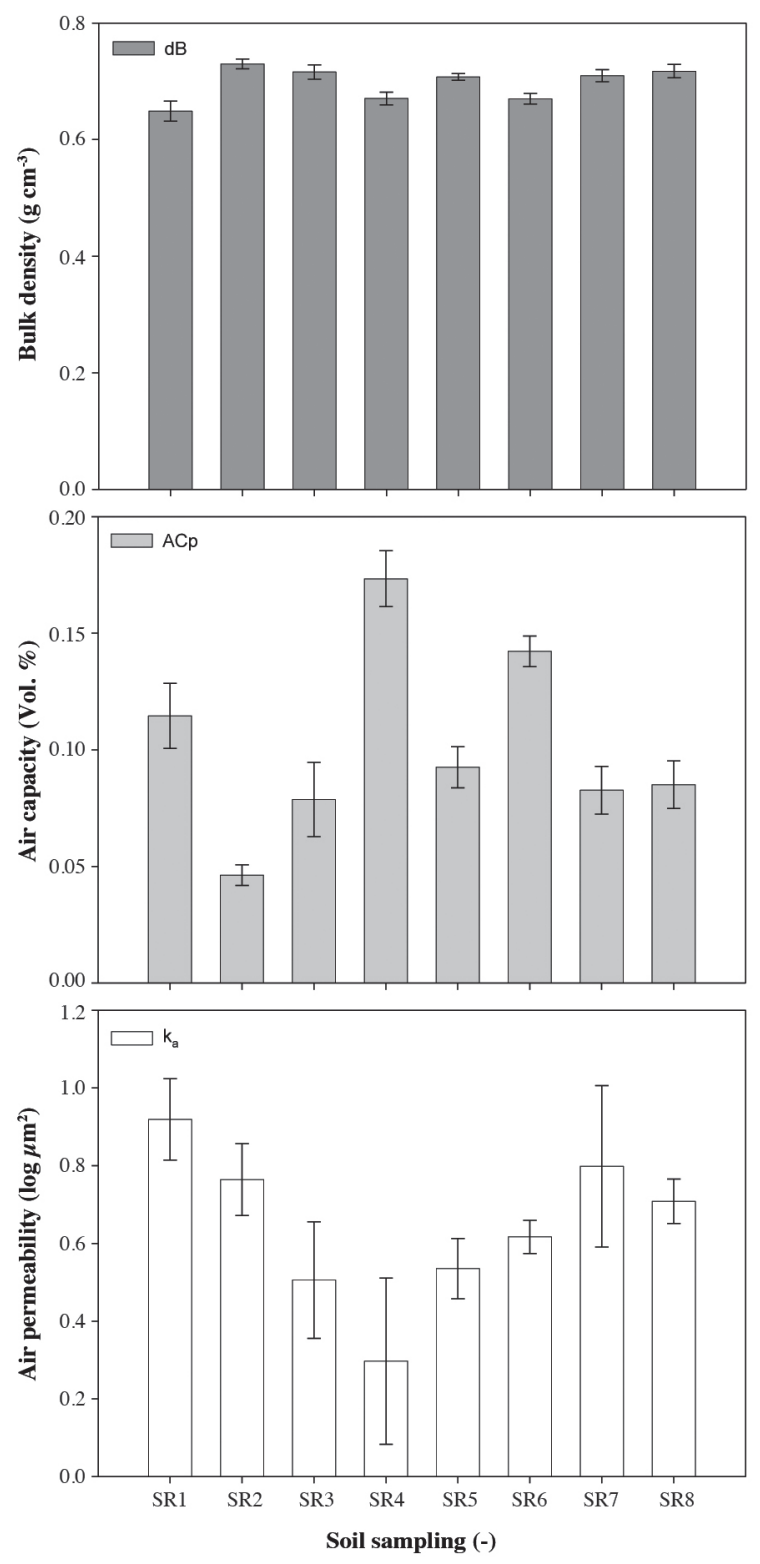

Figure 5. Pore characteristics (dB: bulk density; ACp: air capacity; and $\mathrm{k}_{\mathrm{a}}$ : air permeability) as a function of time (soil samplings SR1 to SR8). Bars indicate \pm 1 standard error $(\mathrm{dB}, \mathrm{n}=7$; $\mathrm{ACp}, \mathrm{n}=7$; and $k a, n=7)$.

grazed soil, as well as changes in bulk density as a consequence of treading and grazing observed only in the top 25 to $60 \mathrm{~mm}$. On the other hand, this property can only be an alternative to explain variations in PR and pore functions since it relates properties to a certain mass per volume without considering particle arrangement in volume. Furthermore, $\mathrm{dB}$ is considered as a low indication parameter to assess subsoil compaction related to crop production. In this case, soil properties related to pore functions, such as air capacity, conductivity, or permeability, were better able to explain variations in soil pore functions (Horn and Fleige, 2009).

Pore functions exhibit time-dependent behavior by showing soil structural changes (Figure 5). Air capacity (ACp) ranges from 5\% to $18 \%$ between SR1 and SR8, and is inadequately related to changes in PR (r: $0.49 ; \mathrm{P}>0.1)$. High air capacity values are common for volcanic soils since they usually show a sandy behavior at large matrix potential values, but a large water-holding capacity at low matrix potential values; this phenomenon is attributable to inter- and intra-aggregate voids, respectively (ArmasEspinel et al., 2003; Dörner et al., 2009b; 2010). Since these types of pores depend on inter-aggregate void formation, they are strongly dependent on soil deformation as shown in Figure 5. Changes in ACp can reach critical values ( $<8 \%$, Horn and Fleige, 2009); however, the soil is also able to recover its initial integrity because of its great resilience capacity (Dörner et al., 2009b). For the same soils, Dörner et al. (2010) assessed 5\% porosity changes between summer and winter simply as a consequence of natural wetting and drying cycles. Air permeability $\left(\mathrm{k}_{\mathrm{a}}\right)$ also changed over time and its values ranged between 0.3 and $0.9 \log \mu \mathrm{m}^{2}$. Air capacity increased between SR2 and SR5, while air permeability clearly decreased, suggesting that grazing events and WD cycles strongly affected pore continuity. A significant negative correlation (r: -0.86; P < 0.01 ) of this property with changes in PR was observed. This relationship could be true since these changes follow changes in soil structure caused by compaction, but cannot be used to forecast changes in $\mathrm{k}_{\mathrm{a}}$. This is true because PR is highly sensitive to changes in WC, but not very sensitive to changes in pore geometry characteristics (pore size distribution and continuity) that strongly affect $\mathrm{k}_{\mathrm{a}}$.

The influence of soil compaction on pore continuity is shown in Figure 6. Air conductivity before consolidation ranged between -2.7 and $-3.7 \log \mathrm{cm} \mathrm{s}^{-1}$, whereas it reached $-4.9 \log \mathrm{cm} \mathrm{s}^{-1}$ after consolidation. These values largely exceeded the critical value of $\mathrm{k}_{1}\left(-2.92 \log \mathrm{cm} \mathrm{s}^{-1}\right)$. This property, in spite of being estimated under laboratory conditions, can be a reference for field grazing events. As abovementioned, grazing animals deform the soil surface by causing aggregate rearrangement in the interaggregate pore space, which leads to PR increase and, in turn, pore reduction. Coarse pores, which are responsible for air transport, are the first to be reduced (Richard et al., 2001; Fujikawa and Miyazaki, 2005) because they are easily deformed (Gebhardt et al., 2009). This further provokes the disruption of porous system connectivity, which causes poor infiltration, decreases both root growth and soil aeration, and reduces hydraulic conductivity between the plough layer and the subsoil causing a lateral flow in the soil slopes (Dörner, 2005). This has negative consequences on crops, which via limited root systems 


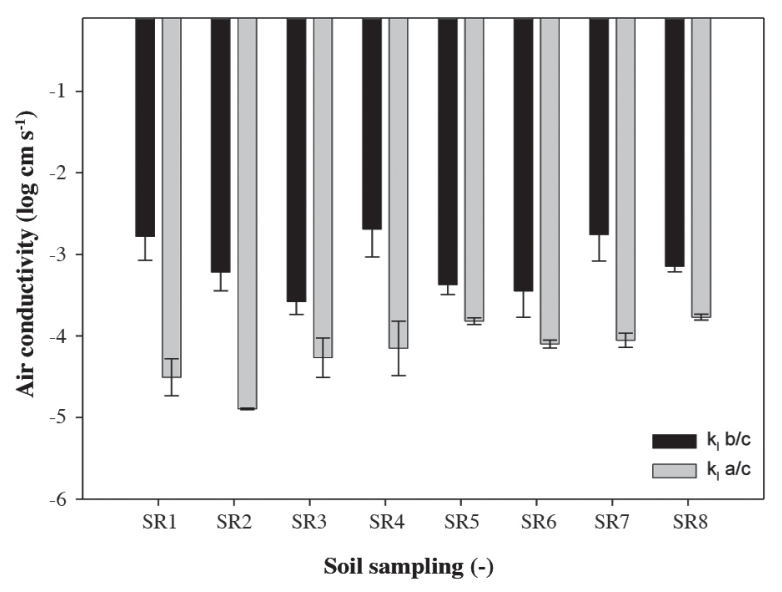

Figure 6. Air conductivity as a function of time before (kl $\mathrm{b} / \mathrm{c})$, and after ( $\mathrm{kl} \mathrm{a/c)} \mathrm{the} \mathrm{consolidation} \mathrm{experiment.}$ Bars indicate \pm 1 standard error $(n=6)$.

are unable to take up sufficient water and nutrients and are susceptible to induced drought, nutrient deficiencies, and aeration stress. Furthermore, reduced efficiency of porous systems also influences soil biological life since impaired water and air movement impedes earthworm mobility that can lead to their extinction. Drewry (2006) pointed out that the loss of important beneficial activities carried out by the organisms (soil loosening, role in organic matter formation, plant growth, and biopore creation) delays soil recovery after compaction.

\section{CONCLUSIONS}

The penetrometer and TDR are easy tools to assess spatial and temporal variations in soil strength. However, the penetrometer cannot be used to estimate changes in soil pore functions.

Soil strength is influenced by soil water content since water menisci forces govern soil susceptibility to compaction and thus, the magnitude of penetration resistance. However, during grazing, animals generate irregular soil compaction causing high spatial variability of penetration resistance not related to changes in water content, which is clearly observed on maps prepared from field data.

Grazing, as well as wetting and drying cycles, induces changes in pore functions (e.g., air capacity and permeability). This indicates that structure-dependent properties are dynamic by showing temporal and spatial changes as a consequence of mechanical and hydraulic stress. Soil deformation normally reduces air capacity and permeability after grazing events; however, the soil is able to recover its functional integrity after wetting and drying cycles because of the great resilience capacity of the volcanic ash soil under study.

\section{ACKNOWLEDGEMENTS}

The first author thanks the FONDECYT Postdoctoral Program 3090038. The study was sponsored by the "Consorcio Lechero" Project M2P12 (4101.39.14). We appreciate the revision of English usage by Christine Harrower.

\section{RESUMEN}

Variaciones temporales y espaciales en las propiedades que dependen de estructura de un suelo derivado de cenizas volcánicas bajo pastoreo en el Sur de Chile. Las praderas son la principal fuente de alimentación del ganado en el sur de Chile. El objetivo de esta investigación fue definir cómo afectan los eventos de pastoreo y ciclos naturales de mojado y secado (WD), la variabilidad temporal y espacial de las propiedades estructurales del suelo. La investigación fue realizada en un Duric Hapludand, Serie Valdivia. La resistencia a la penetración (PR) y el contenido volumétrico de agua (WC) determinados in situ fueron usados para preparar mapas que muestran i) que ellas cambian en el tiempo (PR: 1383-3047 kPa para WC: 46-16\%) y espacio, y ii) que los eventos de pastoreo son un factor importante que influye sobre la variación espacial de PR (diferencias de $3421 \mathrm{kPa}$ entre los valores max y min). El pastoreo y WD inducen cambios en la estabilidad mecánica y la función de los poros indicando que las propiedades estructurales son dinámicas. En permeabilidad de aire $\left(\mathrm{k}_{\mathrm{a}}\right)$ se detectaron variaciones entre 0,3 y $0,9 \log \mu \mathrm{m}^{2}$ durante el período de estudio, mientras que la capacidad de aire osciló entre 5 y 18\%. La estabilidad mecánica también varió en el tiempo reflejando los cambios en PR. Este instrumento, sin embargo, no puede ser usado para identificar variaciones en las funciones de los poros del suelo. Generalmente, después de los eventos de pastoreo, la deformación del suelo provocó una reducción en la capacidad y permeabilidad de aire, sin embargo, después de WD, los poros del suelo fueron capaces de recuperar su integridad.

Palabras clave: resistencia a la penetración, contenido de agua, estabilidad mecánica, sistema poroso, Andisol.

\section{LITERATURE CITED}

Aguayo, M., A. Pauchard, G. Azócar, y O. Parra. 2009. Cambio del uso del suelo en el centro sur de Chile a fines del siglo XX: Entendiendo la dinámica espacial y temporal del paisaje. Revista Chilena de Historia Natural 82:361-374. 
Armas-Espinel, S., J. Hernández-Moreno, R. MuñozCarpena, and C. Regalado. 2003. Physical properties of "sorriba"- cultivated volcanic soils from Tenerife in relation to andic diagnostic parameters. Geoderma 117:297-311.

Bachmann, J., K. Contreras, K.H. Hartge, and R. MacDonald. 2006. Comparison of soil strength data obtained in situ with penetrometer and with vane shear test. Soil and Tillage Research 87:112-118.

Balocchi, O. 2002. Praderas y recursos forrajeros en la zona sur de Chile. p. 59-73. In Amtman, C., F. Mujica, y B. Vera (eds.) Pequeña agricultura en la Región de Los Lagos, Chile. Ediciones de la Universidad Austral de Chile, Valdivia, Chile.

Batey, T. 2009. Soil compaction and soil management - a review. Soil Use and Management 25:335-345.

Bengamin, J.G., D.C. Nielsen, and M.F. Vigil. 2003. Quantifying effects of soil conditions on plant growth and crop production. Geoderma 116:137-148.

Beutler, A.N., F.J. Centurion, and A.P. Silva. 2005. Soil resistance to penetration and least limiting water range for soybean yield in a Haplustox from Brasil. Brasilian Archives of Biology and Technology 48:863-871.

Bilotta, G.S., R.E. Brazier, and P.M. Haygarth. 2007. The impacts of grazing animals on the quality of soils, vegetation, and surface waters in intensively managed grasslands. Advances in Agronomy 94:237-280.

Borghei, A.M., J. Taghinejad, S. Minaei, M. Karimi, and M.G. Varnamkhasti. 2008. Effects of subsoiling on soil bulk density, penetration resistance and cotton yield in northwest of Iran. International Journal of Agricultural Biology 10:120-123.

Bormann, H., and K. Klaassen. 2008. Seasonal and land use dependent variability of soil hydraulic and soil hydrological properties of two Northern German soils. Geoderma 145:295-302.

Casagrande, A. 1936. Characteristics of cohesive soils affecting the stability of slopes and Earth fill. Journal of Boston Society of Civil Engineering 23:13-32.

Chappell, H.G., J.F. Ainsworth, R.A.D. Cameron, and M. Redfern. 1971. The effect of trampling on a chalk grassland ecosystem. Journal of Applied Ecology 8:869-882.

CIREN. 2003. Estudio agrológico X Región. Tomo 2. 412 p. ISBN 956-7153-49-3. Centro de Información de Recursos Naturales (CIREN), Santiago, Chile.

Dec, D. 2006. Termal properties in Luvisols under conventional and conservation tillage treatment. 120 p. Thesis Dissertation, University Christian Albrechts, Kiel, Germany.

Dec, D., J. Dörner, and R. Horn. 2009. Effect of soil management on soil thermal properties. Revista de la Ciencia del Suelo y Nutrición Vegetal 9(1):26-39.
Dexter, A.R. 1988. Strength of soil aggregates and of aggregate beds. p. 35-52. In Drescher, J., R. Horn, and M. de Boodt (eds.) Impact of water and external forces on soil structure. Catena Verlag, Reiskirchen, Germany.

Dorel, M., J. Roger-Estrade, H. Manichon, and B. Delvaux. 2000. Porosity and soil water properties of Caribbean volcanic ash soils. Soil Use and Management 16:133140 .

Dörner, J. 2005. Anisotropie von Bodenstrukturen und Porenfunktionen in Böden und deren Auswirkungen auf Transportprozesse im gesättigten und ungesättigten Zustand. 182 p. Thesis Dissertation, University Christian Albrechts, Kiel, Germany.

Dörner, J., y D. Dec. 2007. La permeabilidad de aire y conductividad hidráulica saturada como herramientas para la caracterización funcional de los poros del suelo. Revista de la Ciencia del Suelo y Nutrición Vegetal 7(2):1-13.

Dörner, J., D. Dec, X. Peng, and R. Horn. 2009a. Change of shrinkage behavior of an Andisol in southern Chile: Effects of land use and wetting/drying cycles. Soil and Tillage Research 106:45-53.

Dörner, J., D. Dec, X. Peng, y R. Horn. 2009b. Efecto del cambio de uso en la estabilidad de la estructura y la función de los poros de un Andisol (Typic Hapludand) del sur de Chile. Revista de la Ciencia del Suelo y Nutrición Vegetal 9:190-209.

Dörner, J., D. Dec, X. Peng, and R. Horn. 2010. Effect of land use change on the dynamic behaviour of structural properties of an Andisol in southern Chile under saturated and unsaturated hydraulic conditions. Geoderma 159:189-197.

Dörner, J., and R. Horn. 2006. Anisotropy of pore functions in structured Stagnic Luvisols in the Weichselien moraine region in N Germany. Journal of Plant Nutrition and Soil Science 169:213-220.

Draghi, L.M., G.F. Botta, R.H. Balbuena, J.A. Claverie, y H. Rosatto. 2005. Diferencias de las condiciones mecánicas de un suelo arcilloso sometido a diferentes sistemas de labranza. Revista Brasileira de Engenharia Agrícola e Ambiental 9(1):120-124.

Drewry, J.J. 2006. Natural recovery of soil physical properties from treading damage of pastoral soils in New Zealand and Australia: A review. Agriculture, Ecosystems and Environment 114(2-4):159-169.

Drewry, J.J. 2008. Soil compaction in pasture grazing systems. SciTopics. Available at http://www.scitopics. com/Soil_compaction_in_pasture_grazing_systems. html (accessed May 2010). 
Drewry, J.J., and R.J. Paton. 2000. Effects of cattle treading and natural amelioration on soil physical properties and pasture under dairy farming in Southland, New Zealand. New Zealand Journal of Agricultural Research 43:377-386.

Drewry, J.J., R.J. Paton, and R.M. Monaghan. 2004. Soil compaction and recovery cycle on a Southland dairy farm: implications for soil monitoring. Australian Journal of Soil Research 42:851-856.

Ellies, A., R. Horn, and R. Smith. 2000. Effect of management of a volcanic ash soil on structural properties. International Agrophysics 14:377-384.

Ellies, A., C. Rámirez, y R. MacDonald. 1993. Variación en la resistencia del suelo por efecto de su uso. Turrialba 43(1):77-82.

Fazekas, O. 2005. Bedeutung von Bodenstruktur und Wasserspannung als stabilisierende Kenngrößen gegen intensive mechanische Belastungen in einer Parabraunerde aus Löss unter Pflug- und Mulch“ saat. 170 p. Thesis Dissertation. University Christian Albrechts, Kiel, Germany.

Fujikawa, T., and Miyazaki. 2005. Effect of bulk density and soil type on the gas diffusion coefficient in repacked and undisturbed soils. Soil Science 170:892901.

Gebhardt, S., H. Fleige, and R. Horn. 2009. Effect of compaction on pore functions of soils in a Saalean moraine landscape in northern Germany. Journal of Plant Nutrition and Soil Science 172:601-614.

German Federal Soil Protection Law. 1998. Gesetzt zum Schutz des Bodens vom 17. 03.1998. BGBI.I. p. 502.

Godwin, R., G. Spoor, B. Finney, N. Hann, and B. Davies. 2008. The current status of soil and water management in England. Royal Agricultural Society of England, Stoneleigh, Warwick.

Greenwood, K.L., D.A. MacLeod, and K.J. Hutchinson. 1997. Long-term stocking rate effects on soil physical properties. Australian Journal of Experimental Agriculture 37:413-419.

Greenwood, K.L., and B.M. McKenzie. 2001. Grazing effects on soil physical properties and the consequences for pastures: a review. Australian Journal of Experimental Agriculture 41:1231-1250.

Hartge, H., und R. Horn. 2009. Die physikalische Untersuchung von Böden. Praxis Messmethoden Auswertung. 178 p. 4. Auflage, Schweizerbart, Stuttgart.

Horn, R., and T. Baumgartl. 2002. Dynamic properties of soils. In Warrick, A.W. (ed.) Soil physics companion. CRC Press, Boca Raton, Florida, USA.
Horn, R., and R. Fleige. 2003. A method for assessing the impact of load on mechanical stability and on physical properties of soils. Soil and Tillage Research 73:8999.

Horn, R., and R. Fleige. 2009. Risk assessment of subsoil compaction for arable soils in Northwest Germany at farm scale. Soil and Tillage Research 102:201-208.

Horn, R., and A. Smucker. 2005. Structure formation and its consequences for gas and water transport in unsaturated arable and forest soils. Soil and Tillage Research 82:5-14.

Horn, R., H. Taubner, M. Wuttke, and T. Baumgartl. 1994. Soil physical properties related to soil structure. Soil and Tillage Research 30:187-216.

Krümmelbein, J., S. Peth, Y. Zhao, and R. Horn. 2009. Grazing-induced alterations of soil hydraulic properties and functions in Inner Mongolia, PR China. Journal of Plant Nutrition and Soil Science 172:769776.

Lapen, D.R., G.C. Topp, M.E. Edwards, E.G. Gregorich, and W.E. Curnoe. 2004. Combination cone penetration resistance/water content instrumentation to evaluate cone penetration-water content relationship in tillage research. Soil and Tillage Research 79:51-62.

Lapen, D.R., G.C. Topp, E.G. Greogorich, H.N. Hayohe, and W.E. Cunroe. 2001. Divisive field-scale associations between corn yields, management, and soil information. Soil and Tillage Research 58:193206.

Lipiec, L., and C. Simota. 1994. Role of soil and climate factors in influencing crop response to soil compaction in Central and Eastern Europe. p. 365-390. In Soane, B.D., and van C. Ouwerkerk (eds.) Soil compaction in crop production. Elsevier, Amsterdam, The Netherlands.

Lloyd, J.E., and N. Collis-George. 1982. A torsional shear box for determining the shear strength of agricultural soils. Australian Journal of Soil Research 20:203-211.

Mead, J.A., and K.Y. Chan. 1992. Cultivation techniques and grazing affect surface structure of an Australian hardsetting soil. Soil and Tillage Research 25:217230 .

Novoa, R., S. Villaseca, S. del Canto, J.L. Rouanet, C.B. Sierra, y A. del Pozo. 1989. Mapa agroclimáticos de Chile. p. 221. Instituto de Investigaciones Agropecuarias INIA, Santiago, Chile.

Peng, X., R. Horn, and A. Smucker. 2007. Pore shrinkage dependency of inorganic and organic soils on wetting and drying cycles. Soil Science Society of America Journal 71:1095-1104. 
Peth, S., and R. Horn. 2006. 11 Consequences of grazing on soil physical and mechanical properties in forest and tundra environments. Ecological studies Vol. 184. Springer Verlag, Berlin Heilderberg, Germany.

Pietola, L., R. Horn, and M. Yli-Halla. 2005. Effects of trampling by cattle on the hydraulic and mechanical properties of soil. Soil and Tillage Research 82:99108.

Proffitt, A.P.B., S. Bendotti, and D. McGarry. 1995. A comparison between continuous and controlled grazing on a red duplex soil. I. Effects on soil physical characteristics. Soil and Tillage Research 35:199-210.

Raper, R.L., D.W. Reeves, C.H. Burmester, and E.B. Schwab. 2000. Tillage depth, tillage timing and cover crop effects on cotton yield, soil strength and tillage energy requirements. Applied Engineering in Agriculture 16:379-385.

Reszkowska, A., S. Peth, and R. Horn. 2009. Cyclic compressibility of grassland soils as affected by grazing in Inner Mongolia, China. ISTRO 18th Triennial Conference Proceedings, Izmir, Turkey. 15 June 2009. International Soil Tillage Research Organisation (ISTRO), The Netherlands.

Richard, G., I. Cousin, J.F. Sillon, A. Bruand, and J. Guerif. 2001. Effect of compaction on the porosity of a silty soil: influence on unsaturated hydraulic properties. European Journal of Soil Science 52:49-58.

Sandoval-Estrada, M., N. Stolpe-Lau, E. Zagal-Venegas, M. Maradones-Flores, y J. Celis-Hidalgo. 2008. Aporte de carbono orgánico de la labranza cero y su impacto en la estructura de un Andisol de la precordillera andina chilena. Agrociencia (México) 42:139-149.

Sears, P.D. 1956. The effect of the grazing animal on pasture. p. 92-101. In Proceedings of the 7th International Grassland Congress, Palmerston North, New Zealand.
Strudley, M.W., T.R. Green, and J.C. Ascough II. 2008. Tillage effects on soil hydraulic properties in space and time: State of science. Soil and Tillage Research 99:4-48.

Unger, P.W. 1991. Overwinter changes in physical properties of no-tillage soil. Soil Science Society of America Journal 55:778-782.

Unger, P.W. 1996. Soil bulk density, penetration resistance, and hydraulic conductivity under controlled traffic conditions. Soil and Tillage Research 37:67-75.

Van den Akker, J.H.H., J. Arvidsson, and R. Horn. 2003. Introduction to the special issue on experiences with the impact and prevention of subsoil compaction in the European Union. Soil and Tillage Research 73:18.

Vanags, C., B. Minasny, and A.B. McBratney. 2004. The dynamic penetrometer for assessment of soil mechanical resistance. SuperSoil 2004, 3rd Australian-New Zealand Soils Conference. 5-9 December. University of Sydney, Sidney, Australia.

Warren, S.D., M.B. Nevil, W.H. Blackburn, and N.E. Garza. 1986. Soil response to trampling under intensive rotation grazing. Soil Science Society of America Journal 50:1336-1340.

Willatt, S.T., and D.M. Pullar. 1983. Changes in soil physical properties under grazed pastures. Australian Journal of Soil Research 22:343-348.

Zhao, Y., S. Peth., J. Krümmelbein., R. Horn., Z. Wang, and M. Steffens. 2007. Spatial variability of soil properties affected by grazing intensity in Inner Mongolia grassland. Ecological Modelling 205:241254. 